\title{
Containing the Spread of Infectious Disease on College Campuses
}

Mirai Shah ${ }^{1}$, Gabrielle Ferra ${ }^{2}$, Susan Fitzgerald ${ }^{3}$, Paul J. Barreira ${ }^{4}$, Pardis C. Sabeti ${ }^{5,6,7,8}$, Andres Colubri ${ }^{5,6,7,9^{*}}$

${ }^{1}$ Harvard College, Cambridge, MA, USA

${ }^{2}$ Brown University, Providence, RI, USA

${ }^{3}$ Harvard University Health Services, Cambridge, MA, USA

${ }^{4}$ Harvard Medical School, Boston, MA, USA

${ }^{5}$ Harvard University, Department of Organismic and Evolutionary Biology, Cambridge, MA, USA

${ }^{6}$ Broad Institute of MIT and Harvard, Cambridge, MA, USA

${ }^{7}$ Howard Hughes Medical Institute, Chevy Chase, MD, USA

${ }^{8}$ Harvard School of Public Health, Boston, MA, USA

${ }^{9}$ University of Massachusetts Medical School, Worcester, MA, USA

* Corresponding author: andres.colubri@umassmed.edu

\begin{abstract}
College campuses are highly vulnerable to infectious disease outbreaks, and there is a pressing need to develop better strategies to mitigate their size and duration, particularly as educational institutions around the world reopen to in-person instruction during the COVID-19 pandemic. Towards addressing this need, we applied a stochastic compartmental model to quantify the impact of university-level responses to past mumps outbreaks in college campuses and used it to determine which control interventions are most effective. Mumps is a very relevant disease in such settings, given its airborne mode of transmission, high infectivity, and recurrence of outbreaks despite availability of a vaccine. Our model allows for stochastic variation in small populations, missing or unobserved case data, and changes in disease transmission rates post-intervention. We tested the model and assessed various interventions using data from the 2014 and 2016 mumps outbreaks at Ohio State University and Harvard University, respectively. Our results suggest that in order to decrease infectious disease incidence on their campuses, universities should apply diagnostic protocols that address false negatives from molecular tests, stricter quarantine policies, and effective awareness campaigns among their students and staff. However, one needs to be careful about the assumptions implicit in the model to ensure that the estimated parameters have a reasonable interpretation. This modeling approach could be applied to data from other outbreaks in college campuses and similar small-population settings.
\end{abstract}

Keywords: Infectious disease, mumps outbreak, college campus, stochastic SEIR model, public health intervention, Harvard University, Ohio State University 
medRxiv preprint doi: https://doi.org/10.1101/2020.07.31.20166348; this version posted May 31, 2021. The copyright holder for this preprint (which was not certified by peer review) is the author/funder, who has granted medRxiv a license to display the preprint in perpetuity.

\section{$1 \quad 1 \quad$ INTRODUCTION}

2 College campuses provide ideal breeding grounds for infectious disease. Students live in close

3 quarters, pack into lecture halls, share food and drinks in the dining areas, and engage in intimate

4 contact. Outbreaks in these settings can spread very quickly. Indeed, a meningitis outbreak took

5 place at Princeton University in March 2014, eventually claiming the life of one student. The

6 Centers for Disease Control and Prevention (CDC) reported the attack rate of the disease on

7 Princeton's campus to be 134 per 100,000 students - 1,400 times greater than the national average

8 (1). Recent COVID-19 spread in educational settings (2) forced school closures around the world

9 (3), and motivated the design and implementation of plans for safe reopening $(4,5)$.

A recent string of outbreaks on college campuses involves mumps, once a common

11 childhood viral disease. After introduction of the measles-mumps-rubella (MMR) vaccine in 1977

12 and the two-dose MMR vaccination program in 1989, the number of mumps cases in the US

13 plummeted by 2005. But, despite a vaccinated population, there has been a recent resurgence of

14 mumps, with a steep jump from 229 cases in 2012 to 5833 cases in 2016 (6). Although a typically

15 mild disease in children, up to $10 \%$ of mumps infections acquired after puberty can cause severe

16 complications, including orchitis, meningitis, and deafness. Furthermore, a majority of recent

17 mumps cases have occurred in young adults who had received the recommended two MMR doses.

18 This suggests that vaccine-derived immunity wanes over time, unlike natural immunity -

19 protection acquired from contracting the disease - which is permanent. Lewnard and Grad estimate

20 that $33.8 \%$ of young adults (ages 20 to 24 ) were susceptible to mumps in 1990 , in contrast to the

$2152.8 \%$ susceptible in 2006, as vaccinations have replaced contraction as the source of immunity

22 (7). The temporary immunity from vaccines strengthens the argument for strict containment as a

23 critical line of defense amidst an outbreak. In the case of COVID-19, even with the availability of 
medRxiv preprint doi: https://doi.org/10.1101/2020.07.31.20166348; this version posted May 31, 2021. The copyright holder for this preprint (which was not certified by peer review) is the author/funder, who has granted medRxiv a license to display the preprint in perpetuity. It is made available under a CC-BY-NC-ND 4.0 International license .

24 several vaccines (8), the challenges associated with their wide and quick distribution (9), the

25 substantial asymptomatic and pre-symptomatic transmission of the disease (10), and the possibility

26 of new viral strains with higher transmissibility (11) provide further support for such approaches.

27 The spread of mumps at Harvard University in 2016, and extensive public health measures

28 and documentation, presents an opportunity to closely examine an outbreak on a college campus.

29 Between January 1 and August 31, 2016, 210 confirmed mumps cases were identified in the

30 Greater Boston area, with most detected at Harvard University. Mumps is a highly contagious

31 disease with the potential to travel quickly and pervasively on a crowded college campus. Some

32 of the most notable mumps outbreaks on college campuses occurred in Iowa (12), Indiana (13),

33 and Ohio (14). But, whereas mumps spread rapidly at Ohio State University (OSU) in 2014 and

34 the University of Iowa in 2006 and 2016, Harvard employed a number of interventions that may

35 have helped mitigate spread of the disease and contain it over just a few months (15). The

36 possibility of distinct viral strains resulting in different outbreak dynamics between schools can be

37 safely dismissed, as it was shown by application of genetic epidemiology methods (16) that all

38 mumps outbreaks in the US since at least 2006 have been likely caused by the same mumps lineage,

39 mumps virus genotype $\mathrm{G}$.

The successful containment at Harvard motivates us to explore varied intervention

41 strategies, given the relative costs of prevention. Even if the use of a booster MMR vaccination is

42 proven theoretically to reduce infection and thus potentially prevent outbreaks $(7,12)$, it is unlikely

43 that universities with limited resources will proactively invest in a third dose. A rough cost analysis

44 conducted by Harvard University Health Services (HUHS) showed that, while the total mumps

45 care expenses for Harvard was approximately $\$ 75,000$, the cost of providing a third MMR dose to

46 every member of the Harvard community (at $\$ 83$ per vaccination) was $\$ 1.7$ million (17). Therefore, 
medRxiv preprint doi: https://doi.org/10.1101/2020.07.31.20166348; this version posted May 31, 2021. The copyright holder for this preprint (which was not certified by peer review) is the author/funder, who has granted medRxiv a license to display the preprint in perpetuity.

It is made available under a CC-BY-NC-ND 4.0 International license .

47 at least in the short term, a third MMR dose cannot be the only answer to handling mumps outbreaks; we must consider more immediate solutions and interventions.

In order to understand the effectiveness of interventions aimed at containing mumps

50 outbreaks on a college campus, we constructed an epidemiological model to simulate the dynamics

51 of mumps on such a population and quantify the impact of various interventions. This modeling

52 can be challenging because the number of susceptible students in a college is small compared with

53 population-wide studies, parameters characterizing the interventions are not known, and data is

54 partially observed. Deterministic models are only appropriate when the populations of the

55 compartments are sufficiently large (18). We adopt a modified stochastic susceptible-exposed-

56 infectious-recovered (SEIR) model presented to addresses these issues. We developed this model

57 within the framework of a Partially Observed Markov Process (POMP), which has been applied

58 to introduce structural stochasticity into epidemic models (19). The stochastic nature of the model

59 allows for variability from elements that are not explicitly included, such as class schedules and

60 campus layouts. This model also allows to easily quantify time-varying interventions after fitting

61 the parameters to the observed data, by running simulations under alternative scenarios.

We fit model parameters on case data for Harvard's 2016 mumps outbreak provided by the

63 Massachusetts Department of Public Health (MDPH). We compared it to data from OSU, one of

64 the few universities that had extensive publicly available data through the CDC. awareness campaigns, more aggressive diagnoses where clinical symptoms alone were enough to

67 result in quarantine, and strict isolation of suspected cases -- were crucial in reducing the size and

68 duration of the outbreak. In particular, Harvard's policies drastically increased the reporting rate

69 of infection and shortened the time a person remains infectious in a susceptible population, relative 
70 to the baseline. As a result, one mumps case at Harvard infected less than two susceptible

71 individuals on average, and much less once aggressive diagnosis was in place, compared to cases

72 at non-residential schools like OSU, in which one mumps case infected an average of six

73 susceptible individuals. However, the OSU data suggests that self-isolation could be effective, if

74 adopted rigorously by students. The conclusions from this paper could guide future responses to

75 infectious disease outbreaks on college campuses. Without effective measures in place, highly

76 transmissible diseases like mumps, meningitis, and now COVID-19, spread in these environments

77 at much faster rates than in the overall population and can lead to serious health complications.

78 Simple interventions that ensure most cases are detected, treated, and separated from susceptible

79 individuals make a significant difference. 


\section{2. MATERials AND MethodS}

\section{$83 \quad 2.1 \quad$ Harvard mumps outbreak}

\section{$84 \quad$ 2.1.1 Data}

85 The mumps outbreak at Harvard began in February 2016, when six students reported onset of 86 parotitis to HUHS. For the next three months, the number of cases continued to rise, until finally

87 plateauing in late May and early June. There were two waves of the outbreak - one occurring in

88 the month of March and a larger one occurring in mid-April - totaling 189 confirmed and probable

89 cases (Figure 1). Confirmed cases are those with a positive laboratory test for mumps virus.

90 Probable cases are those who either tested positive for the anti-mumps IgM antibody or had an 91 epidemiologic linkage to another probable or confirmed case $(20,21)$. The majority of these cases

92 received the recommended two doses of MMR (22).

93 We use data provided by MDPH, which documented every mumps case between 2015 and

942017 at schools across Massachusetts (23). This data includes demographics of the patient (gender,

95 age, county, and institution), symptoms and vaccination status, date they reported their symptoms

96 and the date of symptom onset, and lag time between the date of symptom onset and admission to 97 a medical clinic.

$99 \quad 2.1 .2$ Interventions

100 Harvard University employed three main interventions: (i) an email awareness campaign, (ii) more 101 aggressive diagnoses, and (iii) strict isolation of infectious persons.

103 employees, and colleagues with information on the gravity of the outbreak, recommendations on

104 how to prevent transmission, and instructions on how to identify mumps. This raised awareness 
medRxiv preprint doi: https://doi.org/10.1101/2020.07.31.20166348; this version posted May 31, 2021. The copyright holder for this preprint (which was not certified by peer review) is the author/funder, who has granted medRxiv a license to display the preprint in perpetuity.

It is made available under a CC-BY-NC-ND 4.0 International license .

105 throughout the campus. Particularly at the peak of the outbreak, roommates, resident deans, and 106 athletic coaches all played essential roles in reporting potential cases of mumps, so that few cases 107 likely went undetected and untreated by HUHS $(20,21)$.

Second, Harvard acted vigorously to treat and isolate anyone suspected of mumps

109 throughout the outbreak. Initially, due to the disease's non-specific symptoms and less extreme

110 manifestation in vaccinated people, HUHS used positive mumps PCR tests as a necessary ground

111 for diagnosis. Later, on recommendation from the MDPH, HUHS stopped automatically ruling out

112 those with negative PCR results, given that false negatives were quite frequent in vaccinated

113 individuals and that some individuals reported their infection to the clinic belatedly. Isolation or

114 detection of the mumps virus is challenging because the of its transient replication and coincident

115 presence of antibodies (24). In outbreaks among two-dose vaccine recipients, mumps virus was

116 only detected in samples from approximately $30-35 \%$ of case patients if the samples were collected

117 within the first three days following onset of parotitis (25). Anyone who entered HUHS displaying

118 clinical symptoms of mumps was now deemed infected and infectious. This change in the

119 diagnosis protocol took place on April 15, 2016, day 61 of the outbreak (21).

Third and perhaps most notably, Harvard isolated most confirmed or probable cases of

121 mumps. While many universities simply suggest self-isolation in one's room or dormitory (which

122 leaves roommates and friends highly susceptible to the disease), Harvard removed anyone with

123 clinical symptoms of mumps from the population. Of the 230 total cases at Harvard between

124 February 2016 and November 2017, 96 were isolated in alternate housing on campus, while 110

125 were isolated off-site. Although a person remains infectious with mumps for five days, Harvard

126 isolated patients for six days for additional measure (20). 
medRxiv preprint doi: https://doi.org/10.1101/2020.07.31.20166348; this version posted May 31, 2021. The copyright holder for this preprint (which was not certified by peer review) is the author/funder, who has granted medRxiv a license to display the preprint in perpetuity. It is made available under a CC-BY-NC-ND 4.0 International license .

128 fountains with a weak upward flow were repaired in late March when it became apparent that

129 students were directly touching the fountain with their water bottles or mouths (21). In this study,

130 we only considered the first three larger-scale interventions in our models. Figure 1 shows a

131 timeline of the interventions as well as periods when the population was fluctuating (such as during

132 spring and summer break). Around two weeks after HUHS improved its criteria for diagnosis in

133 mid-April, there was a steep decline in the number of new cases. These interventions were possible

134 thanks to the ample resources that Harvard has at its disposal, which may not be available at other

135 universities. Nevertheless, this situation makes Harvard an ideal testing ground for interventions

136 that could not be deployed elsewhere, at least without solid proof of their efficacy. Thus, we

137 quantify the effects of the three main interventions (awareness campaign, aggressive diagnoses,

138 and strict isolation of suspected cases) further in the modeling section of this paper.

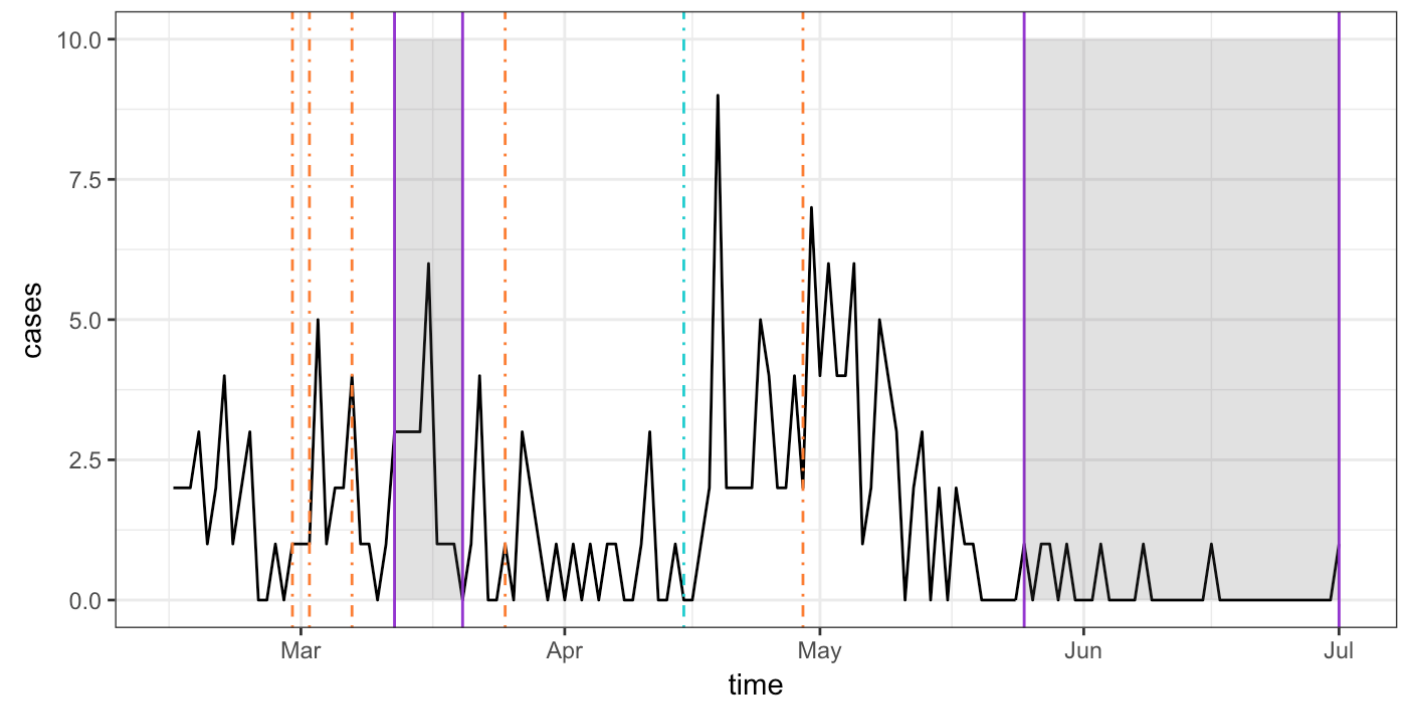

$$
\text { | HUHS email | school vacation | understanding negative PCR tests }
$$

Figure 1: The daily number of new mumps cases (probable or confirmed) at Harvard and the timeline of school vacations and control interventions employed by HUHS between February and June 2016. Both probable and confirmed cases display clinical symptoms of mumps, but only confirmed cases have a positive PCR result. HUHS sent multiple emails over the course of the outbreak, raising awareness about the spread of mumps. Additionally, in mid-April, HUHS began more carefully diagnosing mumps, rather than automatically ruling out those with negative PCR tests. The isolation policy is not shown because it occurred continuously
throughout the entire outbreak. 
medRxiv preprint doi: https://doi.org/10.1101/2020.07.31.20166348; this version posted May 31, 2021. The copyright holder for this preprint (which was not certified by peer review) is the author/funder, who has granted medRxiv a license to display the preprint in perpetuity.

It is made available under a CC-BY-NC-ND 4.0 International license .

\section{$150 \quad 2.2$ Ohio State University mumps outbreak}

\section{$151 \quad$ 2.2.1 Data on the outbreak}

152 In 2014, a large outbreak of mumps occurred in central Ohio, with the majority of cases linked to 153 OSU in Columbus. The outbreak began in February 2014 and peaked in early April with 96 cases

154 in one week. By summer and early fall, the number of cases had dramatically dropped and 155 stabilized (14). We therefore restrict our analysis of the outbreak to the time between Week 1 and 156 Week 40 of 2014, in which there were a total of 528 cases (Figure 2). We obtained this data from 157 CDC's Morbidity and Mortality Weekly Report (26). One drawback of the data is that the cases 158 are reported weekly, making our analysis and parameter estimations less precise. Furthermore, we 159 cannot guarantee that all the cases in this dataset are linked to the university itself, but we know 160 from news reports that most cases in Ohio occurred on campus during the first half of 2014 (14).

161 The proximity in time to the Harvard outbreak and the differences in response detailed below make 162 this a good dataset to compare to.

\subsubsection{Characteristics of the response}

165 We were unable to acquire data directly from OSU, and thus the exact timeline and range of 166 interventions administered over this period are not known. We learned through online searches

167 that advisories were published by the university, notifying students of the issue and how to prevent 168 its spread. One notice published by OSU's medical center reads: "Stay at home for five days after 169 symptoms (salivary gland swelling) begins (required by Ohio law OAC 3701-3-13, (P)); avoid 170 school, work, social gatherings, and other public settings" (27). These advisories were distributed 171 since March 2014 (28), and local news outlets also started reporting the outbreak earlier in the 
medRxiv preprint doi: https://doi.org/10.1101/2020.07.31.20166348; this version posted May 31, 2021. The copyright holder for this preprint (which was not certified by peer review) is the author/funder, who has granted medRxiv a license to display the preprint in perpetuity.

It is made available under a CC-BY-NC-ND 4.0 International license .

month (29). It appears, however, that like most affected universities, OSU did not formally isolate infectious persons.

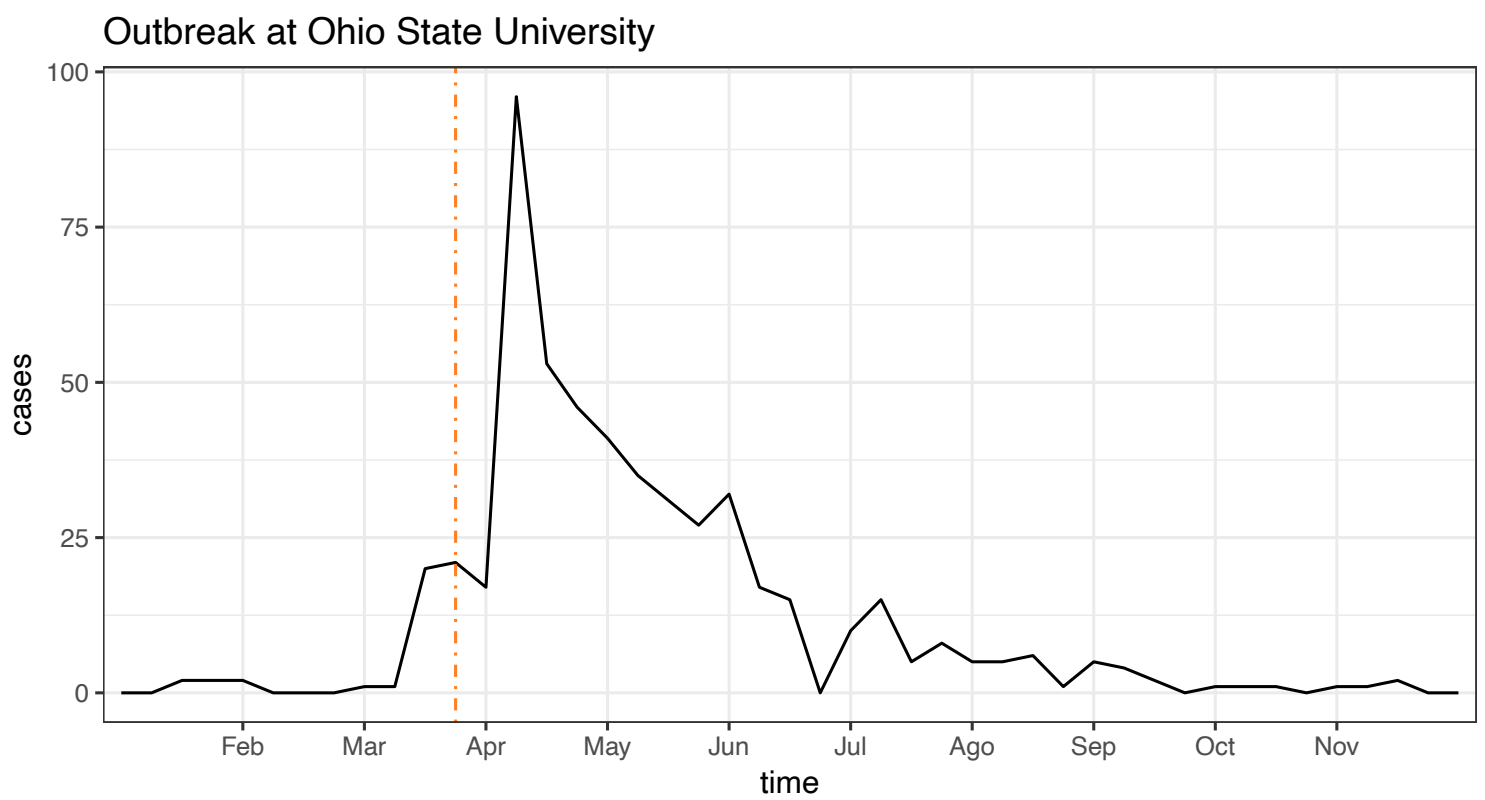

\subsection{Epidemiological POMP model}

179 The epidemiology of mumps can be captured by a Susceptible-Exposed-Infected-Removed (SEIR)

180 compartmental model: after exposure, individuals go through a latent non-infectious period,

181 followed by an infectious phase (30). Infectious individuals are removed from the transmission

182 process either by recovery or isolation, after which they become immune. Compartmental models

183 simplify the mathematical modeling of infectious diseases; however, they assume access to fully

184 observed disease data. In reality, not all mumps cases are reported, and latent mumps carriers

185 exhibit no symptoms at all. In order to address this issue, our approach integrates a standard SEIR 
medRxiv preprint doi: https://doi.org/10.1101/2020.07.31.20166348; this version posted May 31, 2021. The copyright holder for this preprint (which was not certified by peer review) is the author/funder, who has granted medRxiv a license to display the preprint in perpetuity.

It is made available under a CC-BY-NC-ND 4.0 International license .

186

187

188

189

190

191

192

193

194

195

model with a Partially Observed Markov Process (POMP) model (31). This allows us to combine the simplicity of compartmental models with a probabilistic framework for the underlying dynamics and the observed data. POMP models require the specification of a process model that describes stochastic transitions between the (unobserved) states of the system (in this case, the SEIR compartments), and a measurement model where the distribution of observed data (e.g.: confirmed cases) is expressed as a function of the unobserved states. The stochasticity introduced in the SEIR dynamics makes our model better suited to describe small populations, such as college campuses, where random fluctuations can be significant in relation to the size of the population. We describe the process and measurement models below.

\subsubsection{Process model}

The process model, defined as a stochastic SEIR model, provides the change in true incidence of mumps at every time point. We add parameters that induce random fluctuations into the population and change the compartments' rates of transfer in response to interventions. We do this by using probabilistic densities for the transition of state variables. Moreover, although disease dynamics are technically a continuous Markov process, this is computationally complex and inefficient to model, and so we make discretized approximations by updating the state variables after a time step, $\delta$. Due to the varying granularity of the observed data (daily and weekly), we used two different time steps: $\delta_{H}=2.4$ hours for Harvard and $\delta_{O}=12$ hours for OSU. The system of discretized equations is shown in Equation 1, where $B(t)$ is the number of susceptible individuals who become exposed to mumps, $C(t)$ is the number of newly infectious cases, and $D(t)$ is the number of cases that are removed from the population: 

rate $x(t)$, then the probability of remaining in that compartment for an additional day is $\exp (-x(t))$ and the probability of leaving that compartment is $1-\exp (-x(t))$ :

classes at time $\mathrm{t}$ and can be expressed as $\beta(t) \frac{I(t)}{N}$, where $\beta(t)$ represents the transmission rate of the disease. The removal rate between the infectious and removed compartments at time $t$ is given by $\gamma(t)$, and transition rate between the exposed and infectious classes is $\sigma$. Therefore, $\gamma(t)^{-1}$

234 represents the mean length of time a person is infectious before being removed from the population

235 (either because of intervention efforts or natural recovery), while $\sigma^{-1}$ represents the mean length

236 of time a person stays in the latent stage. With this notation, we are implicitly assuming that the 237 transmission and removal rates could change over time due to interventions or changes in behavior, 
medRxiv preprint doi: https://doi.org/10.1101/2020.07.31.20166348; this version posted May 31, 2021. The copyright holder for this preprint (which was not certified by peer review) is the author/funder, who has granted medRxiv a license to display the preprint in perpetuity.

It is made available under a CC-BY-NC-ND 4.0 International license .

238 while the duration of the latent stage is constant and determined by the physiopathology of the

239 disease. We will justify these assumptions for Harvard and OSU next, as well as provide explicit

240 formulas for $\beta(t)$ and $\gamma(t)$.

241 Leaving aside the unlikely possibility of change in pathogen's infectivity, the transmission

242 rate $\beta(t)$ essentially depends on the frequency of exposure events. In the case of Harvard, its

243 nature as a residential campus would lead to significant decreases in student population, and

244 therefore exposures, during school vacations. Exposure at OSU, a non-residential campus, is

245 arguably less affected by vacation breaks. Another potential cause for reduction in exposures is

246 awareness campaigns resulting in the adoption of preventive behaviors by students. Both Harvard

247 and OSU adopted such campaigns, in the former, implemented as emails regularly sent out by

248 HUHS recommending personal hygiene and testing in case of symptoms compatible with mumps;

249 in the latter, in the form of advisories posted around campus and online, advising self-isolation to

250 those students who presented symptoms. Furthermore, due to the scale of the mumps outbreak in

251 Ohio, it received local and national news coverage, particularly in connection with OSU.

252 Anecdotal evidence (i.e.: conversation with students) and, most importantly, the fact that HUHS

253 emails were throughout the outbreak, make us conclude that emails were not particularly effective.

254 On the other hand, news coverage in the case of OSU could have led to additional awareness by

255 students and encouraged some to self-isolate. We argue that self-isolation results in lowering of

256 transmission rate, not shortening of the removal time, because it is not perfect quarantine and

257 people can still interact and become exposed, albeit at a lower frequency. Based on these known

258 facts and our interpretation of them, we propose the following transmission rate $\beta_{H}(t)$ for the

259 Harvard model:

260

$$
\begin{aligned}
\beta_{H}(t) & =p \beta_{H}, \quad t 0 \leq t \leq t 1 \text { or } t \geq t 2 \\
& =\beta_{H} \text { otherwise }
\end{aligned}
$$


medRxiv preprint doi: https://doi.org/10.1101/2020.07.31.20166348; this version posted May 31, 2021. The copyright holder for this preprint (which was not certified by peer review) is the author/funder, who has granted medRxiv a license to display the preprint in perpetuity.

It is made available under a CC-BY-NC-ND 4.0 International license .

262 Here, $t 0$ and $t 1$ represent the starting and ending dates for the spring break (March 12-20 2016),

263 and $t 2$ the beginning of the summer recess (May 26 2016). The constant $\beta_{H}$ is the baseline

264 transmission rate during normal class term, and the parameter $p$ is a number between 0 and 1 that

265 accounts for the reduction of student population on campus during the school vacation. In the case

266 of OSU, we propose:

In this equation, $\beta_{O}$ the baseline transmission rate, $w$ is a constant lower than 1 , and $\zeta$ the time

271 when students began to self- quarantine. Based on publication of public health advisories and

272 local news, we set this time as the last week of March 2014 (week 12). Since Harvard's

273 quarantine was in effect through the entirety of the outbreak, we did not incorporate a similar $w$

274 coefficient to the corresponding $\beta_{H}(t)$ equation for Harvard.

276 know that HUHS diagnosis protocol changed on day 61 of the outbreak at Harvard, resulting in a

277 shorter average removal time since clinical presentation of symptoms alone was enough to result

278 in strict isolation of suspected cases. Thus, we propose the following $\gamma_{H}(t)$ for Harvard:

$$
\begin{aligned}
\gamma_{H}(t) & =q \gamma_{H}, t \geq \tau \\
& =\gamma_{H}, t<\tau
\end{aligned}
$$

281 Here, $q$ is a constant greater than 1 and $\tau$ is the date when the new criteria was implemented (April

$28215,2014)$. The constant $\gamma_{H}$ is the baseline removal rate reflecting the impact of the original 283 diagnosis protocol. In the OSU model, on the other hand, we assume a constant recovery rate $\gamma$

284 equal to the population average for mumps, since infected individuals self-isolate at home. This 285 would not result in a strict quarantine but in a reduced contact rate with susceptible individuals, 286 which is already modeled by a lower transmission rate in equation (4). 
medRxiv preprint doi: https://doi.org/10.1101/2020.07.31.20166348; this version posted May 31, 2021. The copyright holder for this preprint (which was not certified by peer review) is the author/funder, who has granted medRxiv a license to display the preprint in perpetuity.

It is made available under a CC-BY-NC-ND 4.0 International license .

Finally, it is necessary to estimate the basic reproduction number, $R 0$, which equals the

population (30). $R 0$ measures the initial growth rate of an outbreak and so, if it is less than 1 , then

290 the infection will die out and there will be no epidemic. For our stochastic SEIR model, this

291 constant can be expressed as $R 0=\frac{\beta}{\gamma}$ (18). Meanwhile, the time-dependent effective reproduction

292 number is defined as $R_{E}(t)=\frac{\beta(t)}{\gamma(t)} * \frac{S(t)}{N}$, but because $S(t) \approx N$, we can simplify this expression

293 to $R_{E}(t) \approx \frac{\beta(t)}{\gamma(t)}$. Both the basic and effective reproduction numbers allow us to understand the

294 strength of an outbreak.

295

\subsubsection{Measurement Model}

297 Although it is impossible to directly record the number of people that are susceptible, exposed,

298 infectious, and removed directly, the MDPH and CDC data tells us the number of observed cases

299 per day. The mean number of observed cases per day is the true number of cases multiplied by the

300 reporting rate $\rho(\rho<1)$. However, rather than simply denoting the observed number of cases as a

301 binomial distribution, we account for greater variability in the measurements than a binomial

302 distribution expects, since college populations are "small" (comparted to cities and larger

303 administrative units) and more affected by random fluctuations (32). Thus, the number of observed

304 cases, $y_{t}$, given the number of true cases, $C(t)$, can be best modelled by an overdispersed binomial

305 distribution defined as a discretized Normal random variable:

$$
y_{t} \mid C(t) \sim \operatorname{Normal}\left(\rho C(t), \rho(1-\rho) C(t)+(\psi \rho C(t))^{2}\right)
$$

The parameter $\psi$ handles the increased variability in a small population. If $\psi=0$, the

310 variance in our measurement model simplifies to the variance for a binomial distribution. 
medRxiv preprint doi: https://doi.org/10.1101/2020.07.31.20166348; this version posted May 31, 2021. The copyright holder for this preprint (which was not certified by peer review) is the author/funder, who has granted medRxiv a license to display the preprint in perpetuity.

\section{$312 \quad$ 2.3.3 Final POMP Model}

313 The process and measurement models define our final POMP model. For each time point, the

314 process model generates the number of new cases based on binomially distributed counts. The

315 measurement model then estimates the observed number of cases based on the true number of 316 cases and reporting rate. The free parameters in our POMP models for Harvard and OSU that need

317 to be estimated from the data are the following: (i) $\beta_{H}$ and $\beta_{O}$, baseline transmission rates, (ii) $p$ 318 and $w$, decrease in transmission rate at Harvard and OSU due to vacation and self-isolation, 319 respectively, (iii) $\gamma_{H}$ baseline removal rate at Harvard (iv) $q$, increase in removal rate due to the 320 updated HUHS diagnosis protocol, (v) $\rho_{H}$ and $\rho_{O}$, case reporting rates, (vi) $\psi_{H}$ and $\psi_{O}$, 321 overdispersion coefficient representing additional variability in the populations.

\section{$323 \quad 2.3 \quad$ Fixed parameters}

324 In addition to the free parameters to be estimated from the observed case data, our models also

325 include a number of fixed parameters, shown in Table 1, whose values can be inferred directly

326 from previous knowledge or available information. As mentioned earlier, we chose $\tau=61$ days

327 and $\zeta=12$ weeks because those points in time at Harvard and OSU correspond to the introduction

328 of the interventions that we hypothesized to be impactful in the dynamics of the respective 329 outbreaks. Dates $t 0, t 1$, and $t 2$ for the spring and summer vacations at Harvard are available online

330 (33). We set the rate between the exposed and infectious classes and the recovery rate to $\sigma=\frac{1}{17}$

331 and $\gamma=\frac{1}{5}$, respectively, since the average latent period and recovery time for mumps are known 332 to be $\sigma^{-1}=17$ days and $\gamma^{-1}=5$ days (7). Finally, we set the effective population size at Harvard $333 N_{H}=20,000 \times 0.53=10,600$ people based on records of Harvard's enrollment and 
medRxiv preprint doi: https://doi.org/10.1101/2020.07.31.20166348; this version posted May 31, 2021. The copyright holder for this preprint (which was not certified by peer review) is the author/funder, who has granted medRxiv a license to display the preprint in perpetuity.

It is made available under a CC-BY-NC-ND 4.0 International license .

334 employment, and Lewnard and Grad estimation of susceptibility to mumps among college-age

335 adults due to immunity waning (7). Similarly, we use an effective population for OSU given by

$336 N_{O}=60,000 \times 0.53=31,800$, leveraging the total enrollment for the 2013-2014 academic year

337 reported in OSU's statistics website (34).

338

\begin{tabular}{|c|c|c|c|c|}
\hline Symbol & Description & Value & Units & Source \\
\hline$\tau$ & Date of intervention at Harvard & 61 & day & Harvard records on interventions (21) \\
\hline$t_{0}, t_{1}, t_{2}$ & $\begin{array}{l}\text { Vacation dates at Harvard, 2015-2016 } \\
\text { academic year }\end{array}$ & $\begin{array}{c}26,34 \\
100\end{array}$ & day & $\begin{array}{l}\text { Harvard archived academic calendar } \\
\text { (33) }\end{array}$ \\
\hline$\zeta$ & Date of intervention at OSU & 12 & week & \\
\hline$\sigma^{-1}$ & Duration of mumps latent period & 17 & day & Lewnard and Grad (7) \\
\hline$\gamma^{-1}$ & Duration of mumps recovery period & 5 & day & Lewnard and Grad (7) \\
\hline$N_{H}$ & Effective population at Harvard & 10,600 & - & $\begin{array}{l}\text { Harvard records on population size } \\
(22) \text { and mumps susceptibility among } \\
\text { college-aged individuals ( } 7 \text { ) }\end{array}$ \\
\hline$N_{O}$ & Effective population at OSU & 31,800 & - & $\begin{array}{l}\text { OSU's statistical summary (34) and } \\
\text { mumps susceptibility among college- } \\
\text { aged individuals ( } 7 \text { ) }\end{array}$ \\
\hline
\end{tabular}

Table 1: List of fixed parameters used in mumps transmission model for Harvard and OSU

\section{$341 \quad 2.4 \quad$ Maximum likelihood estimation of free parameters}

342 In order to obtain estimates of the free parameters in our models, we pick the parameter values that

343 maximize the log likelihood of the observed data given each model. Within the POMP framework,

344 we can perform fast maximum likelihood estimation (MLE) via Sequential Monte Carlo (SMC)

345 techniques (31). SMC allows us to calculate the likelihood of the data more efficiently by applying

346 the Markov property to generate paths in parameter space that sample the likelihood surface. We

347 performed 100 searches from random parameter guesses, each converging to a unique value, and

348 we then took the maximum over the 100 runs the final point estimates. We did this using the pomp

349 package version 3.3 (35) for the R statistical software version 4.0 .5 (36). In order to calculate the 
medRxiv preprint doi: https://doi.org/10.1101/2020.07.31.20166348; this version posted May 31, 2021. The copyright holder for this preprint (which was not certified by peer review) is the author/funder, who has granted medRxiv a license to display the preprint in perpetuity.

It is made available under a CC-BY-NC-ND 4.0 International license .

350 confidence intervals for each parameter, we applied the Monte Carlo-adjusted profile (MCAP)

351 algorithm (37).

\section{$\begin{array}{lll}353 & 2.5 & \text { Intervention analysis }\end{array}$}

354 Finally, we performed an analysis of the parameters $q$ and $w$, which respectively quantify the effect

355 of what we consider to be the defining intervention at Harvard (aggressive diagnosis) occurring

356 around day 61 of the outbreak, and the self-isolation awareness campaign at OSU during March

357 2014. This could allow us to understand to what extent these interventions made a difference on

358 the trajectory of the outbreak. First, we compared the scenario with the interventions versus a

359 scenario without the interventions. Controlling for all other parameters, we run two sets of

360 simulations at the MLEs, with 200 simulations each. The first set of simulations fixed $q$ and $w$ at

361 the value obtained from MLE, while the second set of simulations set $q$ and $w$ to 1 , assuming that

362 no interventions occurred around day 61 at Harvard and by week 12 at OSU. We then compared

363 the cumulative number of cases over time for these two sets of simulations, generating a $95 \%$

364 percentile range from all the simulations in each set. Second, we used this method to determine if

365 administering the interventions earlier could have lowered the number of cases. For Harvard, we

366 let the day of the intervention take on values between 1 and 60. Subsequently, we ran simulations

367 for each of these 60 cases, pulled the final outbreak size from the median simulation, and calculated

368 the reduction in outbreak size. We applied the same procedure for OSU, in this case varying the

369 day of intervention between 1 and 11 and calculating the corresponding final outbreak sizes. 
medRxiv preprint doi: https://doi.org/10.1101/2020.07.31.20166348; this version posted May 31, 2021. The copyright holder for this preprint (which was not certified by peer review) is the author/funder, who has granted medRxiv a license to display the preprint in perpetuity.

It is made available under a CC-BY-NC-ND 4.0 International license .

\section{RESUltS}

\section{$371 \quad 3.1 \quad$ Optimal Parameters of Harvard and OSU Outbreaks}

372 The MLEs of the parameters provide insight into the key characteristics of Harvard's and OSU's

373 outbreak. In general, we observe very good agreement between the observed cases and the

374 simulated outbreaks using the optimal parameters. The effective reproduction number also reflects

375 the effects of the interventions at Harvard and OSU in way that's consistent with our initial

376 modeling assumptions.

\subsubsection{Maximum Likelihood Estimates for Harvard}

379 The results are shown in Table 2. Notably, the baseline removal rate $\gamma_{H}$ is quite high, indicating

380 that the initial diagnosis protocol was quite effective at identifying and removing infected students

381 from the population, but it was further increased after day 61. The reporting rate $\rho_{H}$ is also

382 remarkably high, which suggests that HUHS was able to identify most of the cases circulating at

383 Harvard.

384

\begin{tabular}{clcccl}
\hline Symbol & Description & Point estimate & $95 \%$ CI & Units & Source \\
\hline$\beta_{H}$ & Baseline transmission rate & 1.39 & $(1.02,2.20)$ & day $^{-1}$ & MLE \\
$\gamma_{H}$ & Baseline removal rate & 0.85 & $(0.78,0.99)$ & day $^{-1}$ & MLE \\
$p$ & Decrease in infection due to vacation & 0.11 & $(0.00,0.47)$ & & MLE \\
$q$ & Increase in removal rate & 2.8 & $(1.39,6.00)$ & - & MLE \\
$\rho_{H}$ & Proportion of infections reported & 0.97 & $(0.87,0.99)$ & - & MLE \\
$\psi_{H}$ & Overdispersion parameter & 0.54 & $(0.36,0.72)$ & - & MLE \\
$R_{E}(t)$ & Effective reproduction number & 1.63 normal term & - & - & Calculated as $\frac{\beta(t)}{\gamma(t)}$ \\
& & 0.18 during vacation & & & \\
\hline
\end{tabular}

Table 2: List of parameters in the Harvard model that were obtained by MLE or calculated using the estimated parameters. 
medRxiv preprint doi: https://doi.org/10.1101/2020.07.31.20166348; this version posted May 31, 2021. The copyright holder for this preprint (which was not certified by peer review) is the author/funder, who has granted medRxiv a license to display the preprint in perpetuity.

It is made available under a CC-BY-NC-ND 4.0 International license .

We ran 200 stochastic simulations of Harvard's outbreak using the parameter values from

388 Table 2. Figure 3A shows the range of values across simulations, and they appear consistent with

389 the observed data. Shortly after day 61 (the time of the primary intervention), we see a decrease in

390 the number of cases. The variability in the simulations can partly be attributed to the randomness

391 in the stochastic model as well as the over-dispersion parameter. Variability can also be explained

392 by the MLE of the basic reproduction number being below 2, which together with the stochasticity

393 built into the simulations, can result in absence of outbreak.

\subsubsection{Maximum Likelihood Estimates for OSU}

396 The MLEs of the parameters for the OSU model, as well as derived quantities, are shown in Table

397 3. Here we can see an initial reproductive number of almost 6, much higher than Harvard's.

398 However, it eventually becomes lower than 1, which supports our modeling assumptions of an

399 awareness campaign from OSU, perhaps helped by news reporting about the outbreak, that lead to

400 effective self-isolation of individuals.

\begin{tabular}{clcccc}
\hline Symbol & Description & Point estimate & $95 \%$ CI & Units & Source \\
\hline$\beta_{O}$ & Transmission rate constant & 1.19 & $(0.92,1.43)$ & day $^{-1}$ & MLE \\
$w$ & Decrease in infection due to self-isolation & 0.16 & $(0.09,1.17)$ & - & MLE \\
$\rho_{O}$ & Proportion of infections reported & 0.03 & $(0.03,0.08)$ & - & MLE \\
$\psi_{O}$ & Overdispersion parameter & 0.38 & $(0.22,0.65)$ & - & MLE \\
$R_{E}(t)$ & Effective reproduction number & 5.95 initial & & - & Calculated as $\frac{\beta(t)}{\gamma(t)}$ \\
\hline
\end{tabular}

Table 3: List of parameters in the OSU model that obtained by MLE or calculated using the estimated parameters.

403 As with Harvard, we run stochastic simulations of OSU's outbreak using the parameter values

404 from Table 3. The simulated outbreaks are shown in Figure 3B, and they follow the real data

405 remarkably well. However, the proportion of infections reported, $\rho_{O}$, is very low at $3 \%$. This would 
medRxiv preprint doi: https://doi.org/10.1101/2020.07.31.20166348; this version posted May 31, 2021. The copyright holder for this preprint (which was not certified by peer review) is the author/funder, who has granted medRxiv a license to display the preprint in perpetuity.

It is made available under a CC-BY-NC-ND 4.0 International license . the total count at around 15,000 .

A - Simulations of Harvard model

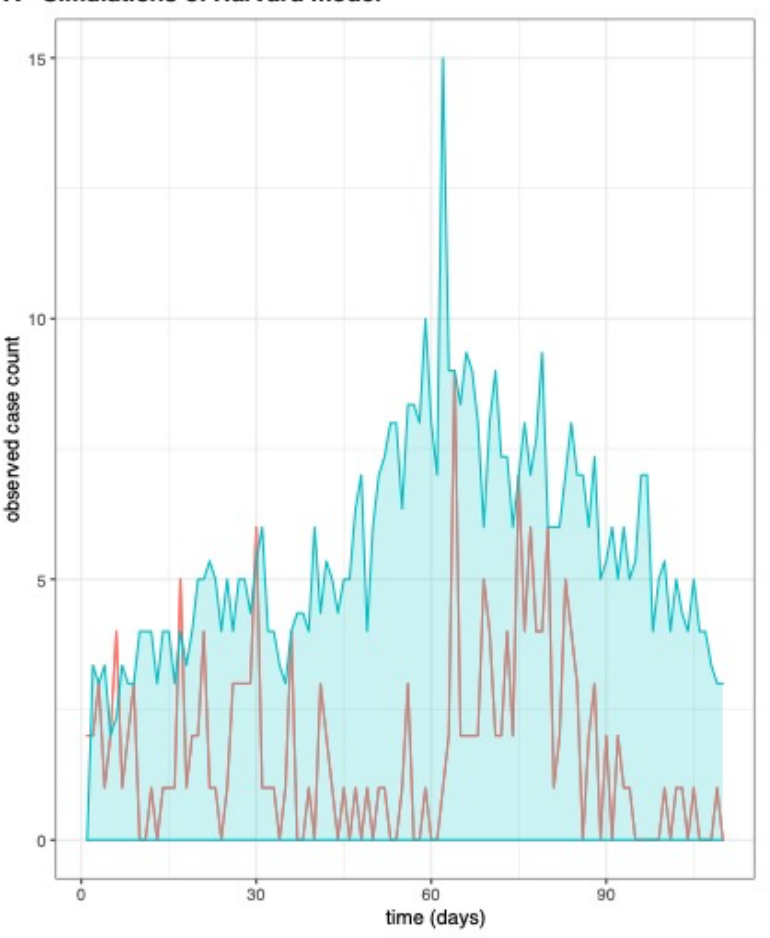

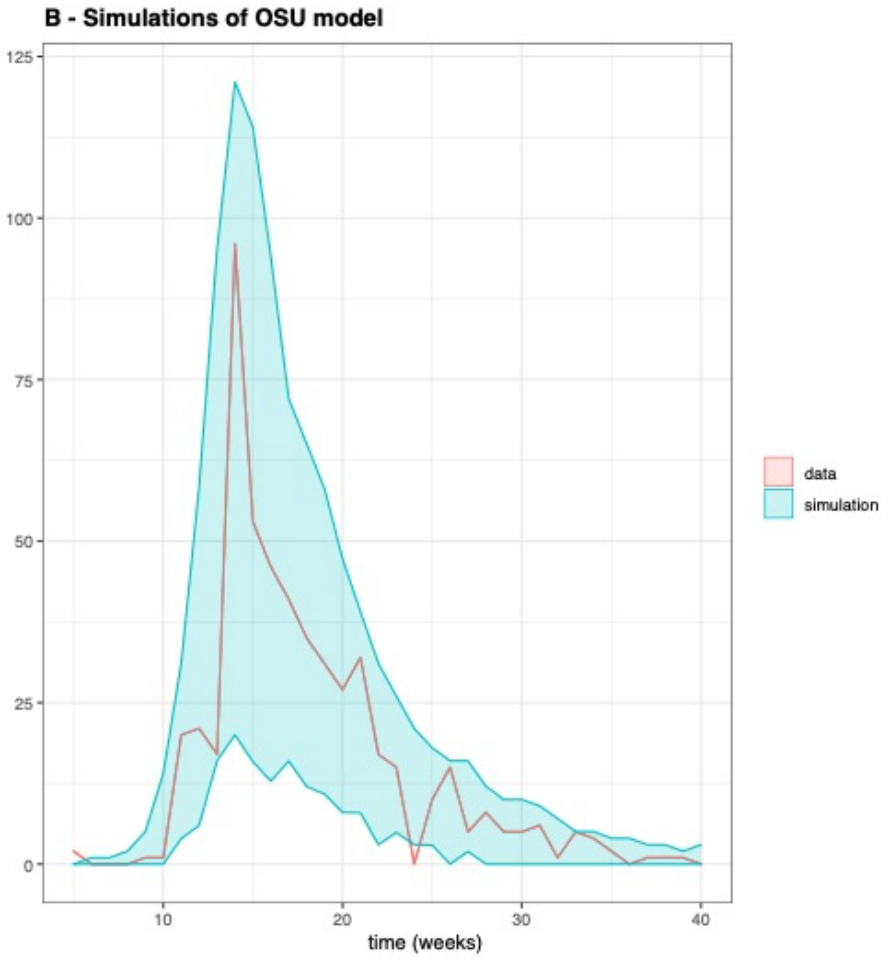

Figure 3: These plots show the observed case count data (red line) and the range of simulated case count values at each time point between the bottom 5\% and top 95\% percentiles (blue shaded area) from 200 simulation runs using the Harvard (A) and OSU (B) models evaluated at the maximum likelihood estimates of the parameters.

\section{$414 \quad 3.2 \quad$ Earlier intervention decreases outbreak size at Harvard and OSU}

415 The results from the intervention analysis for Harvard and OSU is depicted in Figure 4. By the

416 final day of the Harvard outbreak (day 130), the simulations without the intervention on day 61

417 yielded outbreak sizes that were up to four times the size of the actual outbreak (Figure 4A). These 
medRxiv preprint doi: https://doi.org/10.1101/2020.07.31.20166348; this version posted May 31, 2021. The copyright holder for this preprint (which was not certified by peer review) is the author/funder, who has granted medRxiv a license to display the preprint in perpetuity.

It is made available under a CC-BY-NC-ND 4.0 International license .

418 results also indicate that the outbreak would have lasted much longer, if not for these vigilance-

419 increasing strategies. By varying the day of the intervention from 1 to 61 , we also obtained a linear

420 regression between day of intervention and reduction of the outbreak (Figure 4C). The fitness of

421 the regression is very high $\left(\mathrm{R}^{2}=0.96, \mathrm{P}<10^{-9}\right)$, and quick inspection of the plot reveals that if the

422 new diagnosis protocol had been implemented within the first 10 days of the outbreak, then no

423 more than 50 students would have been infected in total at Harvard.

$424 \quad$ For OSU we observe similar trends. Lack of intervention on week 12 could have resulted

425 in an outbreak twice as large (Figure 4B). The outbreak size as a function of the intervention week

426 also shows a strong dependency, but in this case non-linear and best fit with a sigmoid function of

427 the form $1 /\left(1+\mathrm{e}^{\text {week-12}}\right)$. Using this transformation, the fit is also very high $\left(\mathrm{R}^{2}=0.63, \mathrm{P}<0.005\right)$, and

428 we can conclude that intervening earlier would have had a major effect as well: if the awareness

429 campaigns prompting students to self-isolate had started around week 5 or 6 (rather than week 12),

430 then it appears likely that the outbreak could have been completely eradicated. 
medRxiv preprint doi: https://doi.org/10.1101/2020.07.31.20166348; this version posted May 31, 2021. The copyright holder for this preprint (which was not certified by peer review) is the author/funder, who has granted medRxiv a license to display the preprint in perpetuity.

It is made available under a CC-BY-NC-ND 4.0 International license .

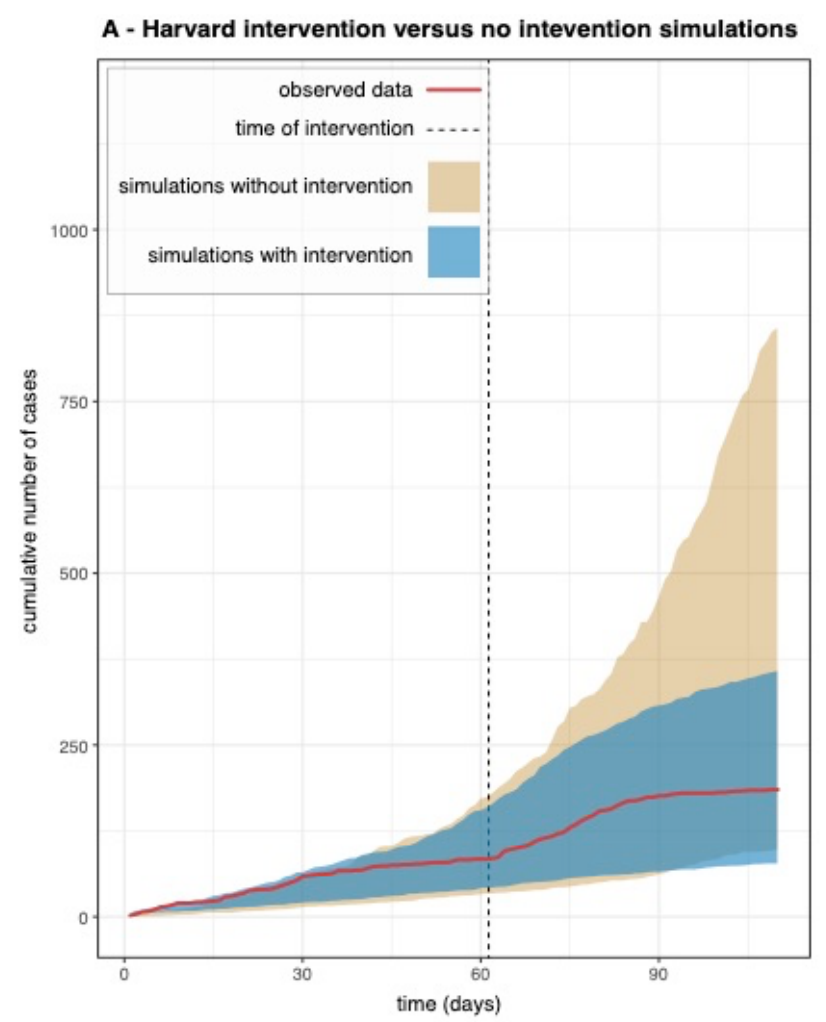

\section{C - Harvard reduction in outbreak by earlier intervention}

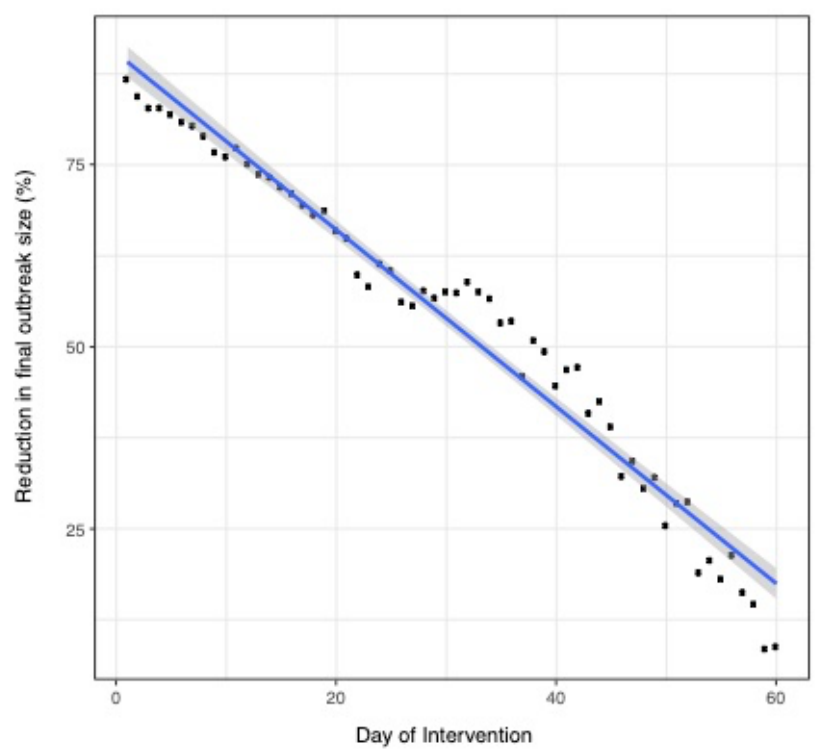

B - OSU intervention versus no intevention simulations

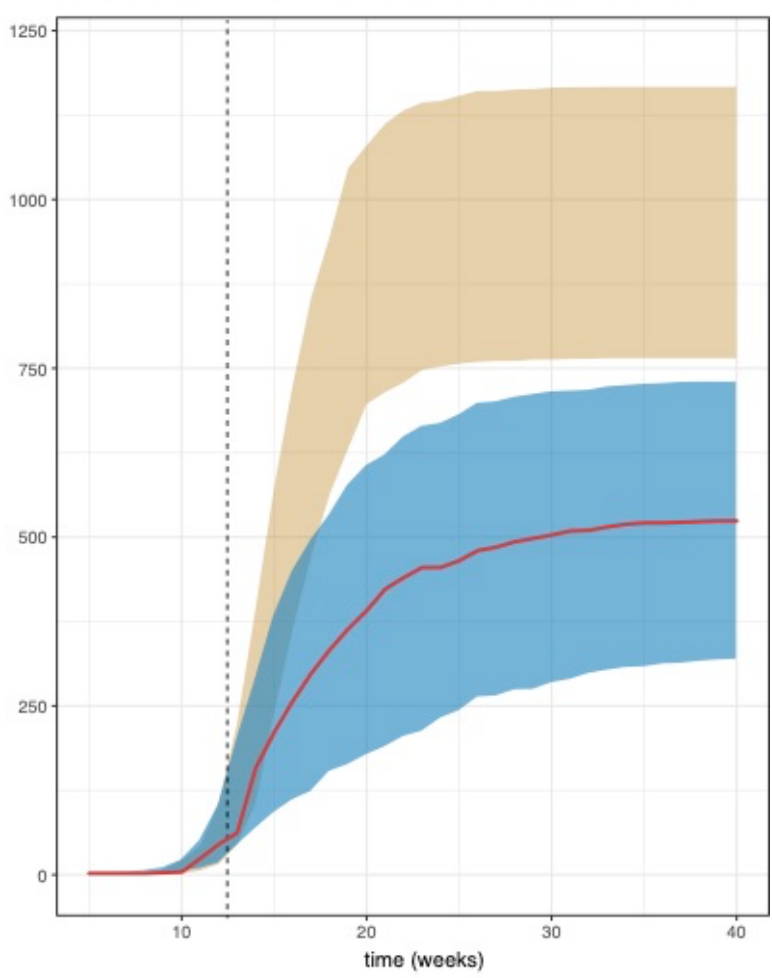

D - OSU reduction in outbreak by earlier intervention

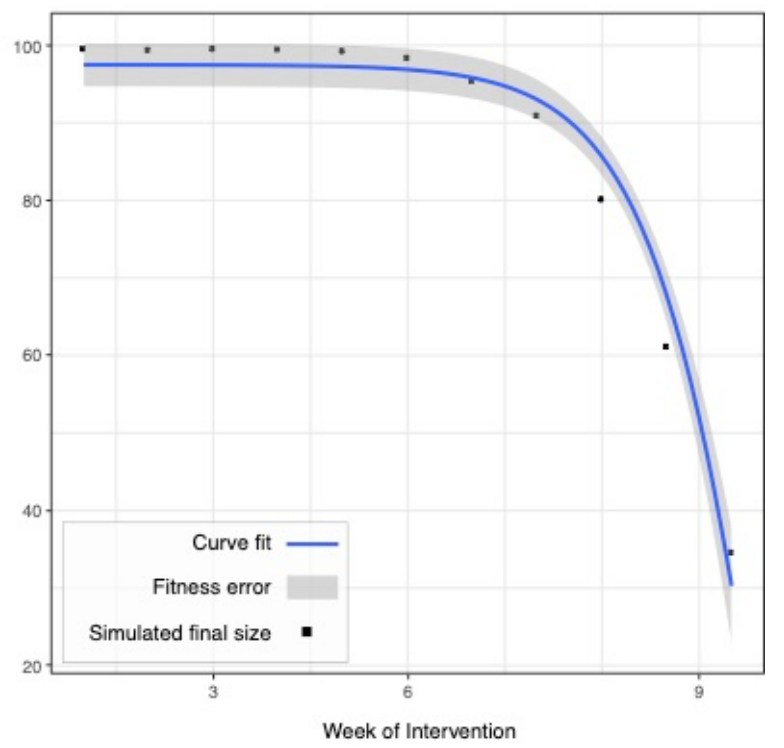

Figure 4: Panels A and B show the comparison of the cumulative number of cases over time for the observed Harvard and OSU data and the range of cases (95\% percentile of the runs) in simulations with and without interventions, with dotted lines representing the timing of the interventions in each school (panels A and B). In panels C and D, the plots show the percentage we expect outbreak size to decrease by if the date of intervention had been moved up. There is a significant linear relationship between the time and percentage reduction in the case of Harvard, as well as a significant relationship after doing a sigmoid transformation of the time variable in the case of OSU. 
medRxiv preprint doi: https://doi.org/10.1101/2020.07.31.20166348; this version posted May 31, 2021. The copyright holder for this preprint (which was not certified by peer review) is the author/funder, who has granted medRxiv a license to display the preprint in perpetuity.

It is made available under a CC-BY-NC-ND 4.0 International license .

\section{4. DISCUSSION}

\section{$436 \quad 4.1 \quad$ Parameter interpretation}

437 The MLEs give us insight into characteristics of the mumps outbreaks at Harvard University in 4382016 and Ohio State University in 2014, as measured by their effective reproduction numbers $R_{E}$,

439 intervention parameters $q$ and $w$, rates of removal $\gamma$, reporting rates $\rho$, and overdispersion

440 parameters $\psi$. At Harvard, $R_{E}$ during normal class term was 1.63 , which indicates that the

441 outbreak was growing, even though testing and isolation by HUHS resulted in a baseline removal

442 time of only $\frac{1}{0.85}=1.2$ days. This points to the effectiveness of the quarantine system

443 implemented by HUHS. However, a small fraction of false negative cases still managed to escape

444 quarantine and keep the virus under circulation, as indicated by the reproduction number being

445 higher than 1 . The reproduction number goes below 1 during the spring break, which is reasonable

446 given that most students are away due to the residential nature of the Harvard campus. However,

447 transmission resumes after the break. It is only after the implementation of the new diagnosis

448 protocol on day 61, which required isolation if clinical symptoms were present, that had a dramatic

449 effect on the detection and isolation of positive cases, effectively taking the removal time to less

450 than 1 day and the reproductive number below 0.6. Thanks to this key intervention, it was possible

451 to end the outbreak before the beginning of the summer recess.

The estimate of $\rho$ is 0.96 , which implies the reporting rate at Harvard was remarkable.

453 Reasons include the email awareness campaign, a community network - from resident deans to

454 athletic coaches - reporting students and employees who seemed at-risk, and more aggressive

455 diagnoses, particularly towards the end of the outbreak. The estimate for $\psi$ is 0.54 , suggesting that

456 the actual data has more variability than expected under the assumed distribution. If $\psi$ had been 
medRxiv preprint doi: https://doi.org/10.1101/2020.07.31.20166348; this version posted May 31, 2021. The copyright holder for this preprint (which was not certified by peer review) is the author/funder, who has granted medRxiv a license to display the preprint in perpetuity. It is made available under a CC-BY-NC-ND 4.0 International license .

457 approximately 0 , the variance in our measurement model would have simplified to the variance 458 for a binomial distribution. However, because the $95 \%$ confidence interval is $(0.22,0.65)$ and thus

459 does not include 0 , we justify the modelling decision of representing the number of cases as an 460 over-dispersed binomial. Demographic and environmental stochasticity (e.g.: a student during 461 midterm season may be less likely to report symptoms), as well as the interventions themselves

462 (e.g.: reporting may increase temporarily after an awareness email) can result in over-dispersion 463 in the number of reported cases.

In the case of OSU, we obtain a much higher reproduction number at the beginning of the 465 outbreak, near 6 , and a very low reporting rate of $3 \%$. Before discussing these results any further, 466 it is important to keep in mind that we extrapolated OSU cases from state-level reports by the CDC.

467 Furthermore, we did not have direct access to information about the containment interventions 468 adopted by the school, as we did for Harvard, so we were only able to make educated guesses 469 about those possible interventions based on information we found on the web. Within our OSU 470 model, we can conclude that self-isolation of students motivated by the advisories posted by OSU 471 had the intended effect of stopping the outbreak. The effective reproduction number dips below 1 472 after March, which is when the awareness campaign appeared to have started, and when the 473 outbreak gained local and national prominence due to news reporting. A significant issue with the 474 OSU model is the very low reporting rate of $3 \%$ derived from the MLE calculation. This rate 475 implies that the true number of mumps cases during the OSU outbreak should have been 476 approximately 30 times larger than observed. It follows that the total number of cases could have 477 reached 15,000 individuals, which is internally consistent in the model given that the number of 478 susceptible within the school's student population is over 30,000. However, such a large case count 479 is unlikely, as it doubles the highest number of yearly mumps cases reported in the US in the last 
medRxiv preprint doi: https://doi.org/10.1101/2020.07.31.20166348; this version posted May 31, 2021. The copyright holder for this preprint (which was not certified by peer review) is the author/funder, who has granted medRxiv a license to display the preprint in perpetuity.

It is made available under a CC-BY-NC-ND 4.0 International license .

48020 years (38), which was 6,369 in 2016. There is little data on the percentage of asymptomatic

481 mumps infections that would result in non-reporting, but the available evidence points to $15 \%-$

$48230 \%(39,40)$. Seroprevalence studies from the pre-vaccination era indicate a reporting rate of

483 around 4\% (41), which is strikingly similar to the MLE estimate for OSU, but it is hard to imagine

484 such level underreporting in 2014 and in the midst of an active outbreak. Therefore, we are not

485 confident on this parameter estimate, even though the $95 \%$ confidence interval is very narrow at

$486(3 \%, 8 \%)$. Our interpretation of this situation is that the modeling approximation of a closed SEIR

487 compartments is probably less accurate for OSU given its non-residential nature: students there

488 have more opportunity to interact with individuals outside of their school, resulting both in

489 additional transmissions that are not captured by our model, and also in a "buffering" effect due to

490 a largely immune population (outside the college age).

491

$492 \quad 4.2 \quad$ Effect of strict isolation policy

493 Arguably the most critical intervention by HUHS was the isolation requirement for confirmed and

494 probable mumps cases. By taking the Harvard model on its own, we see that the infectious period

495 was already quite low at 1.2 days, even before the update in testing protocols. This conclude that

496 the isolation policy led to a smaller average infectious period for Harvard patients. The MLEs for

497 Harvard and OSU are different for several parameters, most notably basic reproduction number,

498 reporting rate, and rate of transition from the infectious to removed class. Firstly, OSU's basic

499 reproduction number is over four times that of Harvard. Harvard's isolation policy best explains

500 this difference because it physically prevented infectious persons from causing multiple secondary

501 infections, thus suppressing the growth of the outbreak. But as pointed out before, the extremely 
medRxiv preprint doi: https://doi.org/10.1101/2020.07.31.20166348; this version posted May 31, 2021. The copyright holder for this preprint (which was not certified by peer review) is the author/funder, who has granted medRxiv a license to display the preprint in perpetuity.

It is made available under a CC-BY-NC-ND 4.0 International license .

502 low reporting rate inferred from the OSU model makes us less confident in it, so any comparison

503 between the Harvard and OSU outbreaks based on the MLE parameters should be taken with

504 caution.

505

$506 \quad \mathbf{4 . 3}$ Implications of intervention analysis

507 With the benefit of our intervention analysis, we conclude that aggressive diagnoses decreased the

508 size of the Harvard outbreak by approximately three-fourths. Furthermore, for every day of

509 intervention delay, we estimate that the outbreak size would have increased by 1.6 percentage

510 points, extrapolating the regression line in Figure 4C. Likewise, self-isolation prompted by health

511 advisories posted by the university reduced the size of the OSU outbreak by half. Given the non-

512 linear dependency between change in outbreak size and timing of intervention (Figure 4D), the

513 increase would have been even larger in that outbreak. Interestingly, this dependency also implies

514 that self-isolation in the first weeks of the outbreak can be enough to completely stop spread.

515 Clearly, a limitation of this analysis is the assumption that everything remains the same

516 while changing the time of the intervention under consideration. In reality, other factors might

517 come into play if the outbreak becomes larger or smaller, which in turn could affect the dynamics

518 of the outbreak as well as the interventions themselves. However, this analysis still provides a

519 useful hypothetical quantification of the effect of accelerating or delaying interventions designed

520 to contain the spread of an outbreak and here, as expected, the sooner the interventions are

521 introduced, the better the outcomes in terms of outbreak size. Of course, existing constraints in the

522 school's health system could impede fast interventions. In such situations, our method can be 
medRxiv preprint doi: https://doi.org/10.1101/2020.07.31.20166348; this version posted May 31, 2021. The copyright holder for this preprint (which was not certified by peer review) is the author/funder, who has granted medRxiv a license to display the preprint in perpetuity.

It is made available under a CC-BY-NC-ND 4.0 International license .

523 useful to perform a cost-benefit analysis of how late an intervention could be made to still have a

524 significant reduction in the health burden caused by the disease.

\section{$526 \quad 4.4$ Conclusions}

527 We constructed and parametrized a POMP model for the transmission of mumps on college 528 campuses. The POMP model is a computationally efficient approach suitable to small populations

529 that accounts for the noisiness and incompleteness of case data. Moreover, it incorporates 530 parameters that measures the effect of interventions implemented after a given point in time. Given 531 the worldwide crisis caused by the COVID-19 pandemic, such models can be useful to quickly 532 evaluate interventions designed to contain the spread of SARS-CoV-2 once schools reopen in the 533 U.S. and around the world.

534 We compared an outbreak at Harvard University, with its various intervention strategies, 535 to another university outbreak of comparable reported cases at OSU. Importantly, while most 536 literature today focuses on mumps prevention - such as administering third MMR doses to college537 age students - this paper provides quantitative backing for more immediate and less costly 538 approaches to mitigating the spread of mumps and other infectious diseases, most notably COVID-

539 19. Even with widespread availability of vaccines, outbreaks of highly transmissible diseases are 540 still a reality, as mumps exemplifies very clearly. In particular, requiring strict isolation if any 541 symptoms of the disease are presented would significantly reduce transmission and ultimately the 542 size of the outbreak. Effective awareness campaigns that lead to self-isolation of infected 543 individuals with mild symptoms can also have a significant effect in containing the spread of 544 disease and limiting the risk for vulnerable populations. 
medRxiv preprint doi: https://doi.org/10.1101/2020.07.31.20166348; this version posted May 31, 2021. The copyright holder for this preprint (which was not certified by peer review) is the author/funder, who has granted medRxiv a license to display the preprint in perpetuity.

It is made available under a CC-BY-NC-ND 4.0 International license .

\section{$545 \quad 4.4 \quad$ Limitations}

546 Some of our conclusions are likely affected by confounding factors that we cannot control for in

547 this analysis. For example, the outbreak at Harvard started to subside in late April, not long before

548 students finish the semester and leave campus, which would decrease the number of potential

549 infections. The most promising method to determine the exact effect of isolation strategies is

550 through a randomized control trial. Regarding the differences between OSU and Harvard

551 parameters, we must be cautious in taking the OSU estimates at face value given the inconsistency

552 in the reporting rate, which may be indicating a more fundamental limitation of model to represent

553 the OSU outbreak. In addition to that, given that the OSU data consists of weekly reports rather

554 than daily reports of cases, we should expect the estimates for the parameters to be less accurate.

555 Furthermore, the cases are not solely linked to the university. Numerous cases in the data occurred

556 in the greater Columbus area, suggesting that the parameter estimates do not only account for the

557 dynamics of mumps on campus. Lastly, major differences in housing and campus characteristics

558 could have also contributed to differences between the two schools; for instance, OSU's population

559 size is three times that of Harvard, and OSU has larger dorms than Harvard's houses. Interventions

560 used at Harvard simply may not have worked as well at OSU. We were fortunate to have direct

561 access to school administrators who were involved in the response to the 2016 outbreak to discuss

562 HUHS interventions in detail, but we were not able to get the same level of detail for OSU's

563 interventions, as discussed in the main text. More broadly, lack of publicly available datasets, with

564 the exception of CDC reports on OSU's outbreak, is a serious impediment to perform these

565 analyses. Therefore, it will be essential that universities across the US and globe actively share

566 data for comparative analysis, to identify the best intervention strategies to protect college

567 campuses from outbreaks, especially in the post-COVID-19 world. 
medRxiv preprint doi: https://doi.org/10.1101/2020.07.31.20166348; this version posted May 31, 2021. The copyright holder for this preprint (which was not certified by peer review) is the author/funder, who has granted medRxiv a license to display the preprint in perpetuity.

It is made available under a CC-BY-NC-ND 4.0 International license .

568 Competing Interests: We declare no competing interests.

569 Source Code: Available at https://github.com/colabobio/mumps-pomp-models

570 Author's Contributions: MS participated in the design of the study, carried out the data analysis,

571 developed the epidemiological models, generated the conclusions, and drafted the manuscript; GF

572 developed the epidemiological models, and generated the conclusions; AC conceived of the study,

573 participated in the design of the study, coordinated the study, and helped draft the manuscript; SF

574 and PJB provided data on the HUHS interventions and reviewed the final draft of the manuscript;

575 PCS overviewed the study and reviewed the final draft of the manuscript. All authors gave final

576 approval for publication and agree to be held accountable for the work performed therein.

577 Acknowledgements: The authors would like to thank Jonathan Grad and Joseph Lewnard for

578 providing feedback on the study design, Hayden Metsky for reviewing the manuscript, members

579 of MDPH for providing access to the Harvard data, and Bridget Chak and Shirlee Wohl for guiding

580 in the interpretation of the data.

581 Ethics: Usage of Harvard University data for development of the SEIR model was approved by

582 the Massachusetts Department of Public Health (MDPH) through protocol 906066. Harvard

583 University Faculty of Arts and Sciences and the Broad Institute ceded review of secondary analysis

584 to the MDPH IRB through institutional authorization agreements. The MDPH IRB waived

585 informed consent given this research met the requirements pursuant to 45 CFR 46.116 (d). Data

586 from Ohio State University was obtained from the CDC's Morbidity and Mortality Weekly Report

587 2014. The Broad Institute has determined usage of this data constitutes non-human subjects

588 research.

589 Funding: Howard Hughes Medical Institute, US National Institutes of Health. 
medRxiv preprint doi: https://doi.org/10.1101/2020.07.31.20166348; this version posted May 31, 2021. The copyright holder for this preprint (which was not certified by peer review) is the author/funder, who has granted medRxiv a license to display the preprint in perpetuity.

\section{REFERENCES}

590 1. Costill D. College campus outbreaks require timely public health response. Healio 591 [Available from: https://goo.gl/aW7GaT.

592 2. Leidner AJ, Barry V, Bowen VB, Silver R, Musial T, Kang GJ, et al. Opening of Large 593 Institutions of Higher Education and County-Level COVID-19 Incidence - United States, July 6594 September 17, 2020. MMWR Morbidity and mortality weekly report. 2021;70(1):14-9.

595 3. Impact of the COVID-19 pandemic on education Wikipedia, the free encyclopedia2020 596 [updated 30 May 2020. Available from: https://en.wikipedia.org/wiki/Impact_of the COVID$597 \quad 19$ pandemic on education.

598 4. Panovska-Griffiths J, Kerr CC, Stuart RM, Mistry D, Klein DJ, Viner RM, et al. 599 Determining the optimal strategy for reopening schools, the impact of test and trace interventions, 600 and the risk of occurrence of a second COVID-19 epidemic wave in the UK: a modelling study. 601 Lancet Child Adolesc Health. 2020;4(11):817-27.

602 5. Lordan R, FitzGerald GA, Grosser T. Reopening schools during COVID-19. Science (New 603 York, NY). 2020;369(6508):1146.

604 6. Hurtado C. The Rise of Mumps in the United States Outbreak Observatory [Available from: 605 https://www.outbreakobservatory.org/outbreakthursday-1/12/7/2017/the-rise-of-mumps-in-the-

606 united-states.

607 7. Lewnard JA, Grad YH. Vaccine waning and mumps re-emergence in the United States. 608 Science Translational Medicine. 2018;10(433).

609 8. Polack FP, Thomas SJ, Kitchin N, Absalon J, Gurtman A, Lockhart S, et al. Safety and 610 Efficacy of the BNT162b2 mRNA Covid-19 Vaccine. N Engl J Med. 2020.

6119 9. The COVID vaccine challenges that lie ahead. Nature. 2020;587(7835):522.

612 10. Nishiura H, Kobayashi T, Miyama T, Suzuki A, Jung S-m, Hayashi K, et al. Estimation of 613 the asymptomatic ratio of novel coronavirus infections (COVID-19). International Journal of 614 Infectious Diseases. 2020;94:154-5.

615 11. Davies N, Barnard RC, Jarvis CI, Kucharski AJ, Munday JD, Pearson CAB, et al. 616 Estimated transmissibility and severity of novel SARS-CoV-2 Variant of Concern 202012/01 in 617 England. CMMID Repository. 2020.

618 12. Shah M, Quinlisk P, Weigel A, Riley J, James L, Patterson J, et al. Mumps Outbreak in a 619 Highly Vaccinated University-Affiliated Setting Before and After a Measles-Mumps-Rubella 620 Vaccination Campaign —-Iowa, July 2015-May 2016. Clinical Infectious Diseases. 2018;66(1):816218.

622 13. Golwalkar M, Pope B, Stauffer J, Snively A, Clemmons N. Mumps Outbreaks at Four 623 Universities - Indiana, 2016. MMWR Morbidity and mortality weekly report. 2018;67(29):793-7.

624 14. Bixler J, Botelho G. Over 360 cases of mumps in central Ohio, most of them tied to OSU. 625 CNN [Available from: https:/www.cnn.com/2014/05/16/health/ohio-mumps/index.html.

626 15. Mumps Cases and Outbreaks Centers for Disease Control and Prevention [Available from: 627 https://www.cdc.gov/mumps/outbreaks.html.

628 16. Wohl S, Metsky HC, Schaffner SF, Piantadosi A, Burns M, Lewnard JA, et al. Combining 629 genomics and epidemiology to track mumps virus transmission in the United States. PLOS 630 Biology. 2020;18(2):e3000611.

631 17. Isolation Expenses (2016-2017). Harvard University Health Services; 2017.

632 18. Brauer F, Van den Driessche P, Wu J. Mathematical epidemiology: Springer; 2008. 
633 19. Stocks T, Britton T, Höhle M. Model selection and parameter estimation for dynamic 634 epidemic models via iterated filtering: application to rotavirus in Germany. Biostatistics. 2018.

635 20. Barreira P, Fitzgerald S. Personal communication. 2018.

636 21. Correspondence regarding Mumps 2016, Spring to Summer. Harvard University Health 637 Services.

638 22. Mumps List for CDC. Harvard University Health Services.

639 23. Massachusetts Mumps Case Data between 2015 and 2017. Massachusetts Department of 640 Public Health.

641 24. Hviid A, Rubin S, Mühlemann K. Mumps. Lancet. 2008;371(9616):932-44.

642 25. Bitsko RH, Cortese MM, Dayan GH, Rota PA, Lowe L, Iversen SC, et al. Detection of 643 RNA of mumps virus during an outbreak in a population with a high level of measles, mumps, and 644 rubella vaccine coverage. J Clin Microbiol. 2008;46(3):1101-3.

645 26. Morbidity and Mortality Weekly Report. 2014.

646 27. Mumps Outbreak FAQs: The Ohio State University; [Available from: 647 https://www.osu.edu/assets/mumps/faqs.pdf.

648 28. The Ohio State University Mumps Outbreak FAQs: Columbus Public Health; 2014 649 [Available from: http://www.ccchd.com/documents/contentdocuments/doc 235 516.pdf.

650 29. Zeltner B. Mumps outbreak at Ohio State: Five things you need to know 651 cleveland.com2014 [updated January $12 \quad 2019$. Available from:

652 https://www.cleveland.com/healthfit/2014/03/mumps outbreak at ohio_state f.html.

653 30. Martcheva M. An Introduction to Mathematical Epidemiology: Springer; 2015.

654 31. King AA, Nguyen D, Ionides EL. Statistical Inference for Partially Observed Markov 655 Processes via the R Package pomp. Journal of Statistical Software. 2016;69(12):43.

656 32. He D, Ionides EL, King AA. Plug-and-play inference for disease dynamics: measles in 657 large and small populations as a case study. Journal of The Royal Society Interface. $658 \quad 2010 ; 7(43): 271-83$.

659 33. Academic Calendar: 2015-16: Harvard Law School; 2015 [Available from: 660 https://hls.harvard.edu/dept/academics/academic-calendar/academic-calendar-2015-16/.

661 34. The Ohio State University - Statistical Summary: The Ohio State University; 2013 662 [Available from: https://www.osu.edu/osutoday/stuinfo13.php.

663 35. King AA, Ionides EL, Bretó MC, Ellner SP, Ferrari MJ, Kendall BE, et al. pomp: Statistical 664 Inference for Partially Observed Markov Processes. 2020.

665 36. R Core Team. R: A Language and Environment for Statistical Computing. 2019.

666 37. Ionides EL, Breto C, Park J, Smith RA, King AA. Monte Carlo profile confidence intervals 667 for dynamic systems. Journal of The Royal Society Interface. 2017;14(132):20170126.

668 38. Health, United States, 2019: Table 10 [Internet]. 2021. Available from: 669 https://www.cdc.gov/nchs/hus/contents2019.htm.

670 39. Hahné S, Schurink T, Wallinga J, Kerkhof J, van der Sande M, van Binnendijk R, et al. 671 Mumps transmission in social networks: a cohort study. BMC Infect Dis. 2017;17(1):56.

672 40. Bonwitt J, Kawakami V, Wharton A, Burke RM, Murthy N, Lee A, et al. Notes from the 673 Field: Absence of Asymptomatic Mumps Virus Shedding Among Vaccinated College Students 674 During a Mumps Outbreak - Washington, February-June 2017. MMWR Morbidity and mortality 675 weekly report. 2017;66(47):1307-8.

676 41. Levitt LP, Mahoney DH, Jr., Casey HL, Bond JO. Mumps in a general population. A sero677 epidemiologic study. Am J Dis Child. 1970;120(2):134-8. 